OPEN ACCESS

Citation: Alexandra Lima Da Silva, Evelyn De Almeida Orlando (2021) Promise and devotion: catholicism and Girl Guides in Brazil. Rivista di Storia dell'Educazione 8(2): 145-153. doi: $10.36253 /$ rse- 10519

Received: February 25, 2021

Accepted: November 11, 2021

Published: December 16, 2021

Copyright: (C) 2021 Alexandra Lima Da Silva, Evelyn De Almeida Orlando. This is an open access, peer-reviewed article published by Firenze University Press (http://www.fupress.com/rse) and distributed under the terms of the Creative Commons Attribution License, which permits unrestricted use, distribution, and reproduction in any medium, provided the original author and source are credited.

Data Availability Statement: All relevant data are within the paper and its Supporting Information files.

Competing Interests: The Author(s) declare(s) no conflict of interest.

Editor: Pietro Causarano, Università di Firenze.

\section{Promise and devotion: catholicism and Girl Guides in Brazil}

\section{Promessa e devozione: cattolicesimo e Girl Guides in Brasile}

\author{
Alexandra lima Da Silva ${ }^{1}$, Evelyn de Almeida Orlando ${ }^{2}$ \\ ${ }^{1}$ UERJ Universidade do Estado do Rio de Janeiro \\ ${ }^{2}$ PUC-PR Pontifícia Universidade Católica do Paraná \\ E-mail: alexandralima1075@gmail.com; evelynorlando@gmail.com
}

\begin{abstract}
This paper attempts to analyze the main justifications for the expansion of Girl Guides in Brazil, a movement that featured a strong expression of female association, a tactic mobilized by certain female Catholic intellectuals to legitimize their circulation in the public space. It indicates education, culture and assistance as important fronts, in a group of actions aimed at securing the Catholic foundations of Brazilian society. Although the elementary principle of Girl Guides wasn't connected to any one religion or belief, it's possible to assess that the movement in Brazil was strongly intertwined with a religious and moral discourse in the form of the "good Girl Guide", who should be pious and devoted to her promise of serving God and country, with clearly Catholic roots.
\end{abstract}

Keywords: Girl Guides movement, female association, catholic church, Brazil.

Riassunto. Questo articolo tenta di analizzare le principali giustificazioni per l'espansione delle Girl Guides in Brasile, un movimento caratterizzato da una forte espressione dell'associazionismo femminile, una tattica mobilitata da alcune intellettuali cattoliche per legittimare la loro circolazione nello spazio pubblico. Indica educazione, cultura e assistenza come fronti importanti, in un insieme di azioni volte a garantire le basi cattoliche della società brasiliana. Sebbene il principio elementare delle Guide non fosse legato a nessuna religione o credo, è possibile affermare che il movimento in Brasile era fortemente intrecciato con un discorso religioso e morale nella forma della "brava Guida", che dovrebbe essere pia e devota alla sua promessa di servire Dio e la Patria, con radici chiaramente cattoliche.

Parole chiave: movimento delle Girl Guides, associazioni femminili, Chiesa cattolica, Brasile. 


\section{INTRODUCTION}

Girl Guides was a movement founded in England in 1910, created by Baden Powell ${ }^{1}$, with the goal of providing complete education to young women. The spread of Girl Guides around the world was due to the action of Agnes Powell ${ }^{2}$ and Lady Powell ${ }^{3}$, Baden Powell's sister and wife, respectively. Due to Lady Powell's interest, the movement gained international dimensions, since "Her enthusiasm for the noble cause was immediately recognized by guides in every country. Her concern with developing the educational system created by her husband was constant" (Correjo Da Manhã, 08/13/1959, p. 2).

The Girl Guides movement took its first steps in Brazil in 1919. The name of the movement in Brazil, Bandeirantismo, was created by professor Jonathas Serrano $^{4}$, who considered it "applied to the young women in search of the riches of the soul and pure joy" (Correjo Da Manhã, 04/23/1957, p. 16). The Brazilian branch of the movement was organized through the creation of Federação das Bandeirantes, the national federation:

On August 13th 1919 the Federação das Bandeirantes [Girl Guide Federation] was born in Brazil, as a civil society which intends to educate women for their family and Country, strengthened by Christian faith. The Girl Guide organization is done through Federation orientation and according to Baden Powell's methods. It's constituted by a Central Council, which elects an Executive Council, by Area and District Chiefs and by Rangers, Guides, Brownies and Rainbows. People interested in the movement can be members of the Federation, accepting unrestricted the Oath and the Code and following the Federation's rules and guidelines [...]. The Girl Guides' motto is SEMPER PARATA, meaning they are always ready to fulfill their duties and serve God, the Country and their neighbors (Bahiana, Bandeirantes, 1933, p. 48).

\footnotetext{
${ }^{1}$ Robert Stephenson Smith Baden-Powell was born in England on February 22 nd 1857 . He was in the military and created scouting. He used his words and travels to spread the movement throughout the world. He authored various books, among them Scouting for boys (1908) and Aids to scouting (1901). In the field of History of Education, regarding Baden-Powell, special attention should be given to the book A escola de Baden-Powell: cultura escoteira, associação voluntária e escotismo de estado no Brasil, by Jorge Carvalho do Nascimento (2008).

${ }^{2}$ Agnes Smyth Powell, Baden Powell's sister, helped him to establish the Girl Guide movement in 1909 England. She was responsible for reviewing his books and talking to young women, and was chosen the first association president in the United Kingdom (Rodrigues, 2016).

${ }^{3}$ Born Olave St. Clair Soames on February 22nd 1889, Dorset, England. At the age of 23 she married then-general Robert Baden-Powell, becoming known as Lady Baden-Powell. She then became interested in the educational system created by her husband.

${ }^{4}$ Jonathas Serrano (1885-1944) was a Catholic educator, History teacher and author of various books, among them A montanha de Cristo, 1931.
}

There are countless books and papers on the Girl Guides abroad, especially published in English (Hampton, 2011; Christian, 1947). In Brazil, we could find a few pieces in different areas. In the field of Anthropology, Maria Inez Motta's 1988 Master's thesis explored the role of women in the Girl Guide movement in Brazil. In Social Sciences, Samara dos Santos Carvalho analyzed the debate around women's emancipation inside the Federation (2013) and gender relations in the Girl Guides movement (2014). In the field of Physical Education, Herold Júnior and Vaz (2012) studied the representations of the female body and education in the expansion of scouts and guides in the first decades of the 20th Century. There is also the historical research conducted by Lúcia Maria Santos Rodrigues (2016), in which she approaches the movement's hundred years as a social gender struggle.

Specifically in the field of History of Education, we found few works. Analyzing the Correio da Manhã column "As Bandeirantes" ["The Girl Guides"], Silva (2017) explores the relationship between Catholicism and the Girl Guides in Brazil, with a focus on the action of Catholic women. In turn, Brito and Silva (2018) analyzed the correspondence sent to the Bandeirantes magazine - the official publication of Confederação das Bandeirantes do Brasil, the Brazilian Girl Guide Confederation - with the goal of indicating the multiplicity of female voices and their distress, aspirations and perspectives. The analysis of contradictions present in the institutional reformulation of Girl Guides in Brazil was the focus of Fellini's study (2017).

\section{GIRL GUIDES IN THEIR TENSIONS AND CONTRADICTIONS: THE 1968 INSTITUTIONAL REFORMULATION}

The Girl Guide movement can be understood as a kind of female association that, in early 20th Century Brazil, worked as a tactic undertaken by elite women ${ }^{5}$ who wanted further female emancipation and rights to the public space. Those association practices, traditionally analyzed in educational historiography as relating to teaching, extrapolated those limits and extended to fronts such as charity, philanthropy, literature, feminism and scouting. From these spaces, those women created discourse, undertook educational practices and fought, in distinct ways, against a social and cultural model that put them in the background of history. Their actions, even if, in large measure, associated to political and

\footnotetext{
${ }^{5}$ The concept of "elite" being used in this paper follows the perspective
} of Sirinelli (1998). 
social conservatism, show ways in which they affirmed their right to exist as subjects, as women.

According to Ana Paula Vosne Martins (2016, p. 3),

It was in large part through these associations and institutions that Brazilian women started escaping the limits of private life and becoming involved with subjects such as budgets, grants, fundraising, welfare services, statutes, regiments, and also negotiation with people in their circle to find support for benevolence activities. Not much is known about this process. A shadow of silence and oblivion hovers above these activities, in spite of the importance of the work developed by welfare institutions in a time of scarcity or even absence of public welfare.

In the broad historiography production about women developed in Brazilian historiography since the mid1980 s, there's a gap regarding elite women, unless they actively took part in feminist movements or acted in resistance in politics and society, constituting herself as a nearly-isolated voice, often considered ahead of her time (Soihet, 2013).

The Girl Guides movement was created by elite women with a social and pedagogical bent, constituting itself through time as

A history created by women and girls who lived through different periods and advanced in political and social rights, cultural values and customs, seeing two world wars, economic crisis with the harsh known dictatorships in their governments and in different years, in various feminisms and in accelerated knowledge in a single century, the 20th, in various human areas. (Rodrigues, 2016, p. 1)

Thinking about the educational practices developed there means paying attention to a historical-educational issue focused on understanding the cultural and pedagogical models under which different generations were educated in Brazil. It also means looking at a set of habits, behaviors and values which guided the education of Brazilian girls and women. Through this associative movement, women were moved to exert political and social roles, intervening in society.

\section{IN THE TRAILS OF PRINT: BANDEIRANTES}

We understand the Girl Guides movement as a kind of association movement that worked as a possible path for constituting intellectual groups. All association movements promote the creation of sociability networks. In the case of intellectuals, according to Sirinelli (1996, p. 254-255), they organize around a "common ideological or cultural sensibility and more diffuse affinities, although equally determinative, which establish the will and interest in coexistence." Among intellectual sociability structures, Sirinelli highlights magazines as conferring structure to the intellectual field through antagonistic inclusion (friendships, herd loyalty) and exclusion (visions, disruptions) forces. The organization around a magazine, according to Sirinelli (2013), shows some ways in which intellectuals congregate and works as the portrait of a group that's almost always issue from the same social milieu, but can still come to have distinct itineraries and build different destinies. Magazines are therefore considered, according to Sirinelli (1996), as a place for a certain group's moving ideas and intellectual fermentation.

In educational historiography, magazines have been studied as pedagogical instruments, due to their formative uses and finalities, even those that don't fit the scope of education and teaching, namely. According to Orlando (2013), books, magazines, newspapers, booklets, flyers and almanacs are forms of print media used for various educational purposes. This plurality points to an important path of investigation for print history, the "large scale circulation, for numerous uses, of written text multiplied by the printing press" (Chartier, 1998, p. 21).

In the movement's perspective, they had informative and formative aspects following the Scout movement's pedagogical line, as analyzed by Nascimento (2008, p. 171):

Print media about the Scouting movement had formative, instructive and regulatory roles in social life, especially in moral aspects, as well as being tools for educating a civilized man [...]. The idea of morality was an important part of the Scouting movement's culture and concerned the patterns of the civilizing process. The rules of civility were always present in their print media. A kind of civility compatible to what Norbert Elias considered the civilized man, that is, one who was capable of exerting control on his passions, rejecting what his heart wanted, acting against his feelings, containing pleasure and the moment's inclination through predicting unpleasant consequences if his impulses were followed.

The Bandeirantes magazine, beyond its pedagogical function, as it circulated news, orientations and experiences that should serve as inspiration for its readers, worked with the political end of creating a structure of intellectual sociability inside the movement. In this scenario, a prominent name in the Brazilian Girl Guides was Maria de Lourdes Lima Rocha, also known simply as "Chief Lourdes". A teacher and educationalist, she founded Companhia do Sagrado Coração de Jesus [Sacred Heart Company], in the neighborhood of Botafogo, and was the founder and director of Bandeirantes magazine: 
Lourdes Lima Rocha was the personification of a Chief Guide. Her rapturous temperament would sometimes lead to debate, but with her cheer, open mind and human understanding, she would soon congregate, around her affectionate and radiant personality, whoever approached (Correjo Da Manhã, 04/23/1957, p. 16).

In 1926, Lourdes Lima Rocha was invited by Father Leovigildo Franca ${ }^{6}$ to found a Girl Guide company. Companhia do Sagrado Coração de Jesus [Sacred Heart Company] worked in the priest's parish's head office, at 42 R. Benjamin Constant. The Federação Bandeirante Brasileira was also built in the land behind the parish church. The Catholic Church's support, in Brazil, was present in various other moments:

In March 1927, the Cardinal Archbishop of Rio de Janeiro, D. Sebastião Leme blesses the Girl Guides. In May of the same year, Companhia do Sagrado Coração de Jesus begins publishing a small newspaper, entitled Bandeirantes, the very same that since 1931 is the [national federation] F.B.B.'s official media (Correjo Da Manhã, 04/23/1957, p. 16).

Although the facts regarding its beginnings are not very precise, what is known is that Bandeirantes was created by Chief Lourdes, at Companhia do Sagrado Coração de Jesus, as a local newspaper (Silva, 2017). Later, it was considered the national federation's official media and, finally, transformed in the movement's national magazine (Rodrigues, 2016). ${ }^{7}$

For that reason, the first copies of the movement's values' print propaganda were sometimes presented as a newspaper, and other times as a magazine. It was published monthly, founded by Companhia do Sagrado Coração de Jesus, and its newsroom and offices were found at $42 \mathrm{R}$. Benjamin Constant. Single copies were sold for $1 \$ 000$ in 1933 , but it could also be acquired through simple subscriptions, protection and honor.

In addition to reports, leadership messages, advice, playful activities, and correspondence, the paper printed features on personalities considered important to the cause. The May 1933 issue featured Gilda Rocha Miranda's speech, read at the Santana Eucharistic Congress. The Chief Guide stated that Catholic youth should resist

\footnotetext{
6 Father Leovigildo Franca was the brother of Father Leonel Franca, which indicates the influent religious advisory the movement got since its inception.

7 The print media dispersion is quite large. At the National Library we could only find the 1928 issue. However, in the archives of the Brazilian Federation, all issues are available for research. Still, the issues analyzed in this paper were those from the years 1933, 1944, 1945, the first issues to which we had access in our research, found and acquired in secondhand bookshops in Rio de Janeiro.
}

their passions and follow the path of virtue: "We shall be pure! We shall be apostles! We shall be saints! So that, through us, Christ may live, Christ may reign, Christ may lord over humanity" (Miranda, Bandeirantes, May 1933, p. 3).

\section{THE GIRL GUIDE OATH: GOD, COUNTRY AND HOME}

Swearing the oath in front of the flag featuring the Girl Guide symbol is part of the girl's initiation ritual. The oath should be honored through following a code, establishing that "a girl guide's feeling is sacred, and her word deserves all trust" (The Editor, Bandeirantes, 1946, p. 1). A Girl Guide should bow to order and hierarchy, being loyal to God and country above all else.

In her paper "O movimento bandeirante, sua organização e propaganda no Brasil" ["The Girl Guide movement, its organization and expansion in Brazil"], Rosita Sampaio Bahiana (The Editor, Bandeirantes, October 1933, p. 46) stated that:

Since Brazil is an essentially Catholic country, the Girl Guide's religion is Roman Catholic, which does not prevent girls from other faiths to join. F.B.B. is part of the 11th commission (Catholic Female Youth) of the Rio de Janeiro Catholic Confederation. 'Religion is essential to happiness', says Baden Powell, and the Girl Guide must cultivate her faith with vigor and honesty, always respecting her sisters' different beliefs. Among the evils scourging modern society, the great Chief Scout places irreligion in first place, and, to fight it, he recommends the loyal and constant practice of a clear, strong faith.

Another goal of the Girl Guide movement was home education, i.e., "turning today's young women into tomorrow's perfect mothers and housewives" (The Editor, Bandeirantes, October 1933, p. 46). Therefore, family should be the main foundation in building individuality:

Home should center all our actionable power and from there radiate its strength and goodness in the benefit of others. Because how could a Girl Guide conscientiously fulfill her duty of helping her neighbors if she doesn't help those closest to her? Self-confidence, as we know, should be the driving force of Girl Guide action... and of acting Girl Guides (The Editor, Bandeirantes, 1933, p. 22).

Obedience is a primordial quality in the good Girl Guide's conduct. Obeying is fundamental in order to learn and let oneself be educated. And always with tenderness and optimism, since, in Baden Powell's words, "God didn't create abrupt movements. Housewives and 
mothers aren't made only through conjugo vobis. Many are made through patience, a husband's pocket and their first child's health, often sacrificed to her inexperience" (The Editor, Bandeirantes, 1933, p. 23).

Good Girl Guides should be exemplary, self-sacrificing and selfless, practicing charity and good deeds:

An ardent Catholic, a Brazilian who loves her people can't have fun while there are children who live without faith nor joy. If we went on like this, we would be denying the education our families gave us. But if we believe the Girl Guides movement is necessary, we must practice it enthusiastically; bring it to our parents, brothers, our entire family. With faith in what we do, victory shall be ours! (Bandeirantes, June 1933, p. 28).

In addition to obeying God, the oath also included the practice of Christian charity, since, according to the code, "Girl Guides help their neighbor in every occasion." In the June 1945 issue, the article titled "Copacabana sobe o morro" ["Copacabana up the hill"] gives visibility to the actions of Chief Ginete in the low-income Cantagalo hills, strongly underlining what they considered to be the chief's courage and dedication, since "It's a true effort for a chief to go up the hill twice a week for meetings and education" (Bandeirantes, June 1945, p. 159).

However, these Girl Guides' "well-intentioned" actions - strongly marked by their social place as largely elite women and by a basically racist culture weren't exempt from a prejudice outlook on Black and poor kids:

To say we saw sick, malnourished and abandoned children, miserable hovels and a lack of hygiene would be repetitive. But we also saw Chief Ginette's company: 20 dark, shiny boys in their white uniforms, all of them very courteous, welcoming the Girl Guides from down the hill (The Editor, Bandeirantes June 1945, p. 159).

The action's protagonist is always the selfless Chief, whose mission included the sacrifice of "civilizing" the "poor, black boys from the slums", an arduous task since

it's even harder to teach those kids to be clean, eat well, act courteous and help their neighbors. But Chief Ginette has managed all that. She's an example of dedication for all companies that exist now and will come to exist in the hills of Brazil (The Editor, Bandeirantes, June 1945, p. 159).

In spite the persistent emphasis on good deeds, they shouldn't be exceedingly ostentatious, so as not to settle in laziness and vice. The path for poor kids' salvation should be through education and effort:

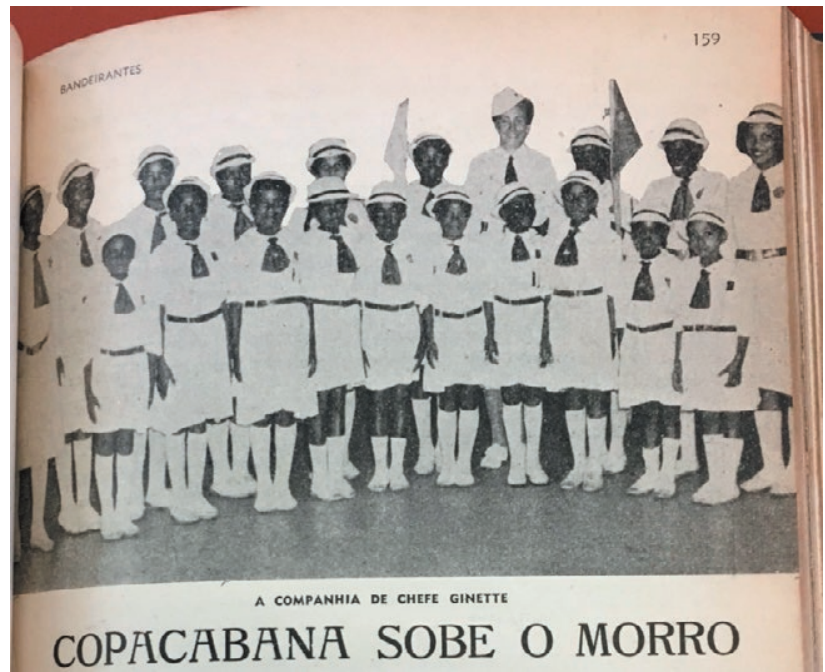

Figure 1. Girl Guides in Cantagalo. Source: Bandeirantes, June 1945, p. 159.

Girl Guides know it's useless to give clothes and food, and they should instead teach how to make clothes and food and provide the means to do so. Education should come from inside the environment. They shouldn't encourage laziness with ostentatious charity. Girl Guides can do much good for the poor. The Girl Guide who has the means feels she should help her sister in the slums and in the factory to have the same opportunities she had. They all wear the same uniforms and have the same ideals. (The Editor, Bandeirantes, June 1945, p. 159).

The promise and mission of service, fundamental aspects of the movement, weren't unscathed by the time's politics and some of the hygienist medical discourses; they even created separate companies for poor girls and those from other religions, such as Jewish girls. That mistake, according to Rodrigues (2016), was only corrected around 1960.

\section{CATHOLIC MORAL AND SOCIAL IDENTITY}

According to Rodrigues, the establishment of the Girl Guides movement in Brazil faced harsh criticism from society, that saw it in unfavorable terms, associated to English masculine education. There was no shortage of press outrage against the movement. However, the association's strength was strategic: "It helped to build a gender identity with new group safety" (Rodrigues, 2016, p. 65). The Church's support was crucial in this process and the presence of Father Leovigildo Franca as spiritual advisor helped to legitimize the movement in the eyes of some of the more conservative sectors, serving as a sort 

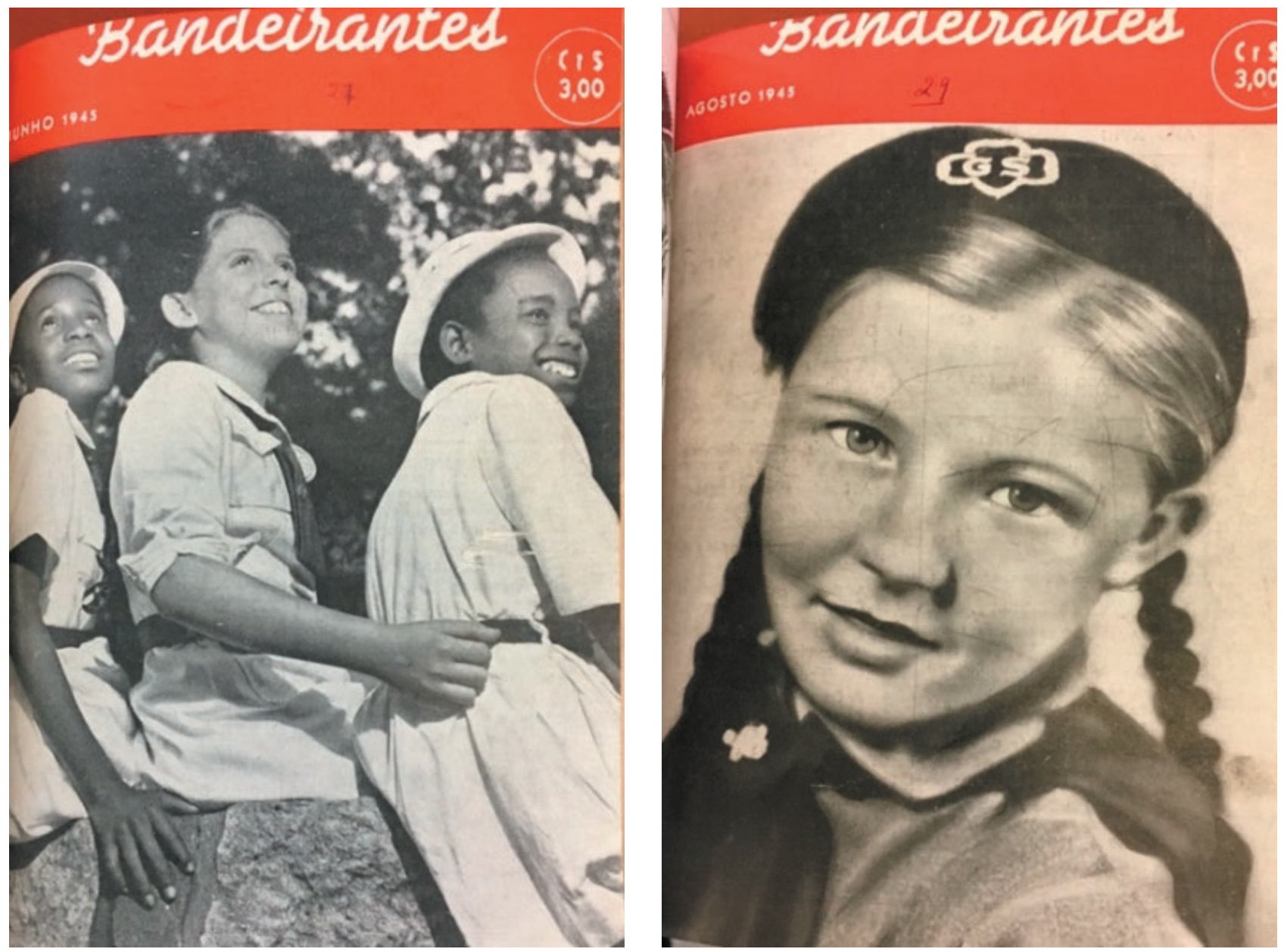

Figure 2. Ethnic and Class Diversity in the Movement. Source: Covers of Bandeirantes magazine, June and August 1945, p. 1.

of guarantee that the movement didn't represent a threat to the moral tentpoles of family and society.

This demystification of the female role and its possibility in the Girl Guides Movement becomes quite clear when they get help from Father Leovigildo Franca in 1926, who stated, referring to the movement: "it's a good path for freedom for women, so that they can form from a young age a newer, more adequate and modern character in her rights, extending to other girls and young women" [...]. And he was a Boy Scout (Rodrigues 2016, p. 67).

After Gilda Rocha Miranda's piece, Bandeirantes shares the summary of the conference given by Father Leonel Franca S. J. at the Sacré Coeur day school on April 20th 1933, under the title "Ação católica e educação" ["Catholic action and education"]. The priest stated that:

Youth is human nature in the best of its energy, so it's not a surprise that the toughest battles are fought around schools. All social movements who don't want to die go knocking on school doors. And if in our days there's so much fighting in the field of education, it's because we find ourselves faced with a great civilization crisis. Well, in this big modern agitation of ideas and principles, we, as Catholics, aren't allowed to cross our arms, complain about the past, bemoan the present and despair the future (Franca, Bandeirantes, May 1933, p. 18).

The Federation's 14th anniversary celebrations also occupied the pages of Bandeirantes. Father Leovigildo Franca's words after the thanksgiving mass had pride of place:

When most members of our Federation - Chiefs and Guides alike - convince themselves of this truth and eagerly dedicate themselves to this personal work of improvement and sainthood, through integrally following the three items in their oaths, and forge the steel temperance of a true character in the furnace of Christian vir- 
tues, then F. B. B. can smoothly march towards conquering the youth, with the certainty of resting on the laurels of victory [...]. The Girl Guide who elevates herself, elevates Brazil (Franca, Bandeirantes, August/September, 1933, p. 3).

Amidst the Federation's 14th anniversary celebrations, they conducted the study A confederação Católica e o Bandeirantismo [Catholic confederation and the Girl Guides], whose conclusions were shared in the magazine:

1-Request that Mr. Cardinal make F.B.B. part of the Catholic Confederation;

2-That Chiefs don't neglect their Girl Guide culture. The lack of specific culture in directors and organizers is important for the movement's failure (The Editor, Bandeirantes, August/September, 1933, p. 9).

The presence of the Church beside the movement gave a social mission disposition to the Girl Guides. Their social identity was forged based on serving their neighbor, on the idea of brotherhood, on the respect of hierarchy, on the work for the common good, and on the loyalty to God and Country, according to the Oath they made when entering the movement.

\section{FINAL THOUGHTS}

Semper parata! Based on this code of moral conduct and rites, the Girl Guide movement attempted to educate girls and young women to become and continue Girl Guides. The magazine Bandeirantes was part of the project of expanding the movement in Brazil, guaranteeing that its ideas and values would circulate throughout the country, from north to south.

Bandeirantes, analyzed in this paper in its early years, shows the amalgamation between the movement and the Catholic Church in Brazil, even though its lord and founder Baden Powell emphasized that the Girl Guide Movement wasn't of a religious nature and shouldn't make distinctions in faith, race or class. Still, what we see printed in the magazine pages are Catholic morality lessons structuring the movement's pedagogy since its foundation, grounding its roots and serving as a compass for all young women who attempted to forge a social identity in the movement.

The involvement of Catholic leadership endorsing the movement gave it, in Brazil, singular aspects when compared to other countries. Initially of an Anglican matrix, in Brazilian society the strength of Catholic culture made itself known, not allowing the movement's pedagogical power to escape and associating it to the current debate around female emancipation, which had been gaining traction among Brazilian intellectuals and had education as its only point of agreement.

It's likely to defend that "Chief Lourdes" and her actions were crucial for the strong Catholic bent of the Girl Guides movement in Brazil, different from other variants, such as the Anglican branch. Lourdes Lima Rocha was Catholic and was one of the founders of Companhia do Sagrado Coração de Jesus in Rio de Janeiro, where the Bandeirantes newspaper was born. We should also highlight the presence of women such as Jeronyma Mesquita, a strong Catholic leader who actively participated in different female associations, including the Federação Brasileira pelo Progresso Feminino [Brazilian Federation for Female Progress], indicating some of the ways in which the Church took part in this debate and formulated a set of practices in dialogue with that which was most modern in the field of education.

The Girl Guides movement is also a strong expression of female association, a strategy employed by some Catholic intellectuals to legitimize their circulation in the public sphere. Education, culture and welfare were, initially, the areas in which they were most involved, politically exerting, from these fronts, a set of actions aimed at safeguarding the Catholic foundations of Brazilian society.

\section{REFERENCES}

Bassanezi, Carla. 1996. Virando as páginas, revendo as mulheres: revistas femininas e relações homem-mulher, 1945-1964. Rio de Janeiro: Civilização Brasileira.

Bicalho, Maria Fernanda Baptista. 1988. O bello sexo: a imprensa, identidade feminina no Rio de Janeiro em fins do século XIX e início do século XX. 268 f. Dissertation (Master's Degree in Social Anthropology) Programa de Pós-Graduação em Antropologia Social do Museu Nacional, Universidade Federal do Rio de Janeiro, Rio de Janeiro,1988.

Brito, Daiane; Silva, Alexandra Lima da. 2018. "Em correspondência: vozes femininas na revista Bandeirantes". In: Ana Chrystina Mignot (Ed.). A ilusão do leitor: cartas, imprensa e educação. Curitiba: CRV, 2018, v. 1, p. 121-142.

Carvalho, Samara dos Santos. 2013. A Federação das Bandeirantes no limiar dos anos sessenta: uma proposta de emancipação da mulher? 2013. 84 f. Undergraduate Thesis (Social Sciences) - Faculdade de Filosofia e Ciências, UNESP, Marília.

Carvalho, Samara dos Santos. 2014. O Movimento Bandeirante e as relações de gênero no contexto 
social brasileiro do século XX. 2014. Dissertation (Master's Degree in Social Sciences) - Faculdade de Filosofia e Ciências, Universidade Estadual Paulista.

Chartier, Roger. 1998. A aventura do livro: do leitor ao navegador. Translated by Reginaldo de Moraes, São Paulo: UNESP; Imprensa Oficial do Estado.

Christian, Catherine. 1947. The big test: the story of the girl guides in the World War. Girl Guides Association, 194.

Fellini, Mariella. 2017. O movimento bandeirante entre tensões e contradições: a reformulação institucional de 1968. 2017. Dissertation (Master's Degree in Education) - Universidade do Vale do Rio dos Sinos.

Freire, Maria Martha de Luna. 2006. Mulheres, mães e médicos: discurso maternalista em revistas femininas (Rio de Janeiro e São Paulo, década de 1920). 2006. Thesis (Doctorate) - Fundação Oswaldo Cruz, Rio de Janeiro.

Hampton, Janie. 2011. How the Girl Guides Won the War. New York: HarperCollins Publishers.

Herold Jr, Carlos; Fernandez Vaz, Alexandre. 2012. "A educação corporal em Baden-Powell: o movimento escoteiro contra o intelectualismo escolar". Revista HISTEDBR On-line, Campinas, n. 47, p. 166-184, sept. 2012.

Machado Júnior, Cláudio de Sá. 2006. Fotografias e códigos culturais: representações da sociabilidade carioca pelas imagens da revista Careta (1919-1922). 2006. 145 f. Dissertation (Master's Degree in History) Pontifícia Universidade Católica do Rio Grande do Sul, Porto Alegre, 2006.

Martins, Ana Luiza. 2001. Revistas em Revista: Imprensa e Práticas Culturais em Tempos de República, São Paulo (1890-1922). São Paulo: Editora da Universidade de São Paulo; FAPESP; Imprensa Oficial do Estado.

Martins, Ana Paula Vosne. 2016. "Itinerários do associativismo feminino no Brasil: uma história do silêncio". Delaware Review of Latin American Studies, v. 17, n. 2, November 14, 2016.

Motta, Maria Inez F. 1988. Bandeirantismo no Brasil: um estudo de caso sobre mulher e modernidade. 1988. Dissertation (Master's Degree in Social Anthropology) - Programa de Pós-Graduação em Antropologia Social do Museu Nacional, Universidade Federal do Rio de Janeiro, Rio de Janeiro.

Nascimento, Jorge Carvalho do. 2008. A escola de BadenPowell: cultura escoteira, associação voluntária e escotismo de estado no Brasil. Rio de Janeiro: Imago.

Orlando, Evelyn de Almeida. 2013. Educar-se para educar: o projeto pedagógico do monsenhor Álvaro Negromonte dirigido a professoras e famílias através de impressos (1936-1964). 2013. 360f. Thesis (Doctor- ate in Education) - Programa de Pós-Graduação em Educação, UERJ, Rio de Janeiro.

Rodrigues, Lúcia Maria Santos. 2016. Movimento Bandeirante no Brasil: uma Luta Social de Gênero, Rio de Janeiro: S/E.

Sgarbi, Antônio Donizetti. 2001. Bibliotecas Pedagógicas Católicas: estratégias para construir uma civilização cristã e conformar o campo pedagógico através do impresso (1929-1938). 2001. Thesis (Doctorate in Education) - Pontifícia Universidade Católica, São Paulo.

Sgarbi, Antônio Donizetti. 1997. Igreja, educação e modernidade na década de 30: escolanovismo católico construído na CCBE divulgado pela Revista Brasileira de Pedagogia. 1997. Dissertation (Master's Degree in Education) - Pontifícia Universidade Católica, São Paulo.

Silva, Alexandra Lima. 2017. "Lado a lado: marcas católicas do Bandeirantismo no Brasil". Revista História da Educação, v. 21, n. 52, maio/ago 2017.

Sirinelli, Jean-François. 2012. "Interview conducted by Marieta de Moraes Ferreira in Rio de Janeiro", November 5th 2012. Trasncribed by: Charlotte Riom. Translated by: Anne Marie Milon. Revista Brasileira de História, São Paulo, v. 33, n. 65, p. 407-412, 2013.

Sirinelli, Jean-François. "As Elites Culturais". In: Sirinelli, Jean-François. Para uma História Cultural. 259-79. Lisboa: Editorial Estampa.

Sirinelli, Jean-François. 1996. "Os intelectuais". In: Rémond, René (Ed.). Por uma história política. Rio de Janeiro: Editora UFRJ.

Soihet, Rachel. 2013. Feminismos e antifeminismos: mulheres e suas lutas pela conquista da cidadania plena. Rio de Janeiro: 7 Letras.

\section{Sources}

"As bandeirantes festejam 40 anos de fundação do movimento no país". Correio da Manhã, 13/08/1959, p. 2.

Atayhde, Maria José Q. A. de. 1957. "O bandeirantismo e sua história no Brasil”. Correio da Manhã, 23/04/1957, p. 16.

Bahiana, Rosita Sampaio. 1933. "O movimento bandeirante, sua organização e propaganda no Brasil”. Bandeirantes, October 1933, p. 46.

Miranda, Gilda Rocha. 1933 “Congresso Eucarístico de Santana”. Bandeirantes, May 1933, p. 3.

Bandeirantes, 1933, p. 23.

Bandeirantes, April 1933, p. 21.

Bandeirantes, May 1933, p. 18.

Bandeirantes, June 1933, p. 28

Bandeirantes, Aug./Sept. 1933, p. 3. 
Bandeirantes, Aug./Sept. 1933, p. 9.

Bandeirantes, June 1945, p. 159.

Bandeirantes, June and August 1945, p. 1

Bandeirantes, 1946, p. 1. Epigraph 